\title{
The Women of Afghanistan: Past and Present Challenges
}

\author{
Kaan Diyarbakirlioglu \\ Yalova University, Turkey \\ Sureyya Yigit \\ Yalova University, Turkey
}

Received: April 18, 2017 Accepted: June 1, 2017 Published: June 5, 2017

doi: 10.5296/jsss.v4i2.11349ＵRL: http://doi.org/10.5296/jsss.v4i2.11349

\begin{abstract}
Women face tough challenges in developing countries which usually enforce strong traditional stereotypes. Afghanistan is a good example where women have experienced both radical and moderate changes. Some of the changes have ameliorated their position in society whereas for the most part the changes endured have kept them from fulfilling their potential roles in a traditional patriarchal structure. This article attempts to highlight the various fluctuations that have occurred in the $19^{\text {th }}$ and $20^{\text {th }}$ centuries, paying special attention to the period during and after the Soviet invasion of 1978. Afghan women possess legal rights which are on a par with other developed states but it is the implementation of these rights which leaves much to be desired. The impact of culture and history cannot be minimised when trying to explain the obstacles faced in improving Afghan women's rights.
\end{abstract}

Keywords: Afghanistan, Women, Women's rights, Constitution, Patriarchy

\section{The Women of Afghanistan: Past and Present Challenges}

Throughout the ages the roles of men and women have always been a recurrent issue in all societies. In general there is a long history spanning many centuries of women's subjugation and oppression in developing countries. In this vein Afghanistan possesses a deep and fundamental gender divide which has existed for an extended period of time. The status, position and role of women in Afghan society have been different under varying regimes and time periods.

The impact on women has been especially harsh, since women's lives have often been used as the raw material with which to establish ethnic prominence. Tribal laws and sanctions have 
routinely taken precedence over Islamic and constitutional laws in deciding the roles of women, especially through kinship hierarchies in the rural regions (Emadi, 2002). Tribal power plays institutions of honor and inter-tribal shows of patriarchal control have put women's position in jeopardy. Tribal laws view marriages as alliances between groups. Hence they stay in the domestic sphere, observe veil is voiceless. The honor of the family, the tribe, and ultimately the nation is invested in women (Rostami-Povey, 2007). Besides having such a gender based society, the women of Afghanistan participated in economic, social and politically spheres of their societies.

Afghan society is consistent in its attitudes toward the basic principles of the role of women. There is wide range of standards set for accepted female behavior (Mehta, 2002). Manners and behaviors which are accepted for women in Afghan society were received from the distant past. While some Afghan Kings and leaders struggled to change these manners and behaviors in the $19^{\text {th }}$ and $20^{\text {th }}$ centuries, most of the time they remained unsuccessful and the situation of women in Afghanistan today cannot be said to be only the result of the Mujahidin or civil war and Taliban's policies, but also the fact that history effects the current position and situation of women.

\section{The Role of Afghan Women During the $19^{\text {th }}$ and $20^{\text {th }}$ Centuries}

The first significant change concerned King Abdur Rahman establishing a centralized state. Abdur Rahman in 1883 tried to change some of the customary laws that were detrimental to women's status. For instance, he abolished the custom forcing a woman to marry her deceased husband's next of kin, raised the age of marriage, and gave women rights to divorce under specific circumstances (McChesney \& Mehdi Khorrami, 2012). His liberal wife Bobo Jan may have influenced this act. In fact, she was the first Afghan queen to appear in public in European dress without a veil. She rode horses and trained her maids in military exercises. She had a keen interest in politics and discussed politics between contending parties.

The son of Abdur Rahman (1901-1919), Amir Habibullah continued his father's progressive agenda by putting a ceiling on extravagant marriage expenses that often caused poverty in many families (Alikuzai, 2013). His wives were seen publicly unveiled in western clothes.

King Habibullah, opened a school for girls with English curriculum which tribal leaders and mullahs saw as cutting against the grain of tradition. Education for women, and state's interference in marriage institutions challenged the power of tribal leaders and their patrilineal and patrilocal kinship systems, resulting in Habibullah's assassination in 1919.

Habibullah placed his son Amanullah on the throne marking the full-fledged modernization period of Afghanistan. His modernizing agenda included the liberation of women from tribal cultural norms. Amanullah publicly campaigned against the veil, against polygamy, and encouraged education of girls not just in Kabul but also in the countryside (Alikuzai, 2011). At a public function, Amanullah said that Islam did not require women to cover their bodies or wear any special kind of veil. At the conclusion of the speech, Queen Soraya tore off her veil in public and the wives of other officials present at the meeting followed this example. For the first time in 15 years young women were sent to Turkey for higher education in 1928 (Runion, 2007).

By 1928, the ethnic tribal leaders in the rural regions grew restless and developed coalitions 
to protest the freedoms women were experiencing in Kabul. Opposition effectively closed off education for girls, and forced Amanullah to reverse some of his policies and conform to a more traditional agenda of social change. Nevertheless, pressures on Amanullah mounted, and in 1929 he was forced to abdicate and leave the country (Rasanayagam, 2005).

The next two decades of Afghan royalty was a period of chaos with different families and leaders vying for power. After 20 years Nadir Shah held the reins to power, first he opened schools for girls and he tried to do this all over country, second he tried to bring about some gender-based reforms but was careful to avoid conflicts with the mullahs and tribal leaders alongside he was very careful with tribal leaders and the mullahs until he was assassinated.

Zahir Shah came to power in late 1950s believing that there is a need for women to be economically active to help Afghanistan achieve its targeted development goals. Women's issues were once again given some consideration. Prime Minister Mohammad Daoud did not want to repeat the haste and mistakes of his predecessor Amanullah and declared veiling a "voluntary option". By now women were expected once again to abandon the veil, marriage expenses were curtailed, and women were encouraged to contribute to the economy.

The 1940s and 1950s saw women becoming nurses, doctors and teachers and civil servants (Billaud, 2015). In 1964 with the third Constitution, it was allowed for women to enter elected politics and by giving them the right to vote. The first woman Minister was in the health department, elected to Parliament along with three other women, employed in airlines, private corporations, and this was the era that Universities graduated female doctors from Universities of Afghanistan.

This continued until 1973 when Daoud Khan a cousin and brother-in-law of Zahir Shah seized power in a coup. The coup was bloodless and gender issues in this time took another feature. Women got more freedom than at any other time; right to education and freedom to work, women were joining political parties officially, and become representatives of the people in parliament (Runion, 2007). In a very short time a lot of changes were enacted and in 1978 he was overthrown by a pro-soviet political party: People's Democratic Party of Afghanistan (PDPA) and the Democratic Republic of Afghanistan was established (McChesney \& Mehdi Khorrami, 2012).

Legally girls and women got empowered in the Democratic Republic of Afghanistan, with women taking on the roles of teachers, government workers and medical doctors. They also worked as professors, lawyers, judges, journalists, writers and poets. Moreover, women were working in every sphere. Gender based reforms were made during this government. Large numbers of women were initiated into the civil service, education for girls were improved which were obligatory (Kumar, 2004).

In rural areas most of the people was unsatisfied because it was obligatory though such reforms were not universally well-received, being viewed by many Afghans particularly in rural areas, as the obligation of secular western values considered to be alien and unfamiliar to the Afghan culture and un-Islamic.

The new government for the reason of their lack of understanding of the complexities of Afghan society and because they did not extend the benefits to the majority of the population, prepared the grounds for a widespread rural revolt against themselves. In 1979, Soviet troops 
invaded Afghanistan, the Cold War intensified and the Afghan Mujahedeen became the US-backed anti-Soviet force.

In the 1960s and 1970s, middle- and upper-class women in Kabul had access to education and employment and moved freely around the city without veiling themselves. Moreover, women in Kabul and other major cities worked as scientists, pharmacists, teachers, medical doctors and civil servants. They were different from the majority of women in urban and rural areas who lived in poverty and were excluded from this emancipatory process favoring urban areas, certain classes and ethnic groups (Dupree \& Albert, 1974). The Democratic Republic of Afghanistan decided on a radical way of becoming liberal and emancipating society.

Therefore, in 1978 Afghanistan faced Soviet occupation with the Soviets leaving Afghanistan only in 1989. During the Soviet war, many civilians including numerous women and children were killed. It should not be forgotten that it was women who were at the forefront in opposing the Soviet Army. (Ellis, 2000). However, in the Afghan capital and in some of the major cities under the communist government's control, women enjoyed some basic freedoms (Amstutz, 1994).

At the same time women in rural areas were oppressed and demoralized by the invasion of the USSR. The Soviets tried to provide more opportunities for women, but in tribal based areas participation of women outside of the house was unrealistic for them. But during the war most women in the country lost at least one relative and thousands of families had to leave the country because of Soviet invasion.

\section{2001: An Opportunity to Improve the Role of Women}

One of the main claims of the Bush Administration to justify the "Operation: Enduring Freedom" that led to the U.S. military invasion of Afghanistan on October 7, 2001, concerned the idea of Afghan women being oppressed during the war and by the Taliban (Yigit, 2009). On November 11, 2001, First Lady Laura Bush delivered the first ever radio address to the people of Afghanistan by a woman, expounding the atrocities against women done by terrorists:

Afghan women know, through hard experience, what the rest of the world is discovering: The brutal oppression of women is a central goal of the terrorists. Long before the current war began, the Taliban and its terrorist allies were making the lives of children and women in Afghanistan miserable. ... Only the terrorists and the Taliban forbid education to women. ... Because of our recent military gains in much of Afghanistan, women are no longer imprisoned in their homes (Meyerowitz, 2003).

After the overthrowing of the Taliban in November 2001, the new government (Karzai and his administration) and at the same time the international community, new strategies were taken toward Afghanistan, where the situation and rights of women was also mentioned. Ministry of Women Affairs was created in the new government for focusing and deliberating women issues.

After November 2001, change came albeit slowly. Most of the women remained uneducated and poor. (Brodsky, 2004). Violence remained a constant threat. The problem of womens illiteracy and limited educational possibilities were at the forefront. (Skaine, 2008). There continued to be many professions which were forbidden to women. (Bush, 2017). The 
pressures on women had spilled over onto even girls who were disguised as boys. (Nordberg, 2014).

In most institutions and organizations women were still not visible, and the reason centering on their personal safety. Several issues exist related to gender in Afghanistan from 2001 until the present as Afghan women still do not have basic rights, education facilities, cultural barriers that prohibit female from several activities and actions, violation of customs and culture against women's rights such as Jirgas (councils of male elders), early child and forced marriages, selling daughters and exchanging daughters. It should be mentioned that these issues related to gender do not exist from 2001, it covers a long history which includes civil wars, conflicts, and invasions which affects present Afghan society.

According to Chapter 2, Article 22(2) of the constitution of Afghanistan "the citizens of Afghanistan, man and woman, have equal rights and duties before the law" (Hancock, 2011). While the reality is that Afghan women do not enjoy the basic rights which the constitution gives them. Article 22(1) of the Afghan Constitution is about "any kind of discrimination and distinction between citizens of Afghanistan shall be forbidden." (ibid) For understanding the reason why Afghan women do not have the equal rights is related to understanding Afghan society as a whole, with the constitution remaining as a symbol.

In the process of drafting a new Constitution of Afghanistan, the issue of women's rights will likely remain a controversial issue, either openly or discretely, and will again be a symbol for what direction the nation should take. If the issue of women's rights is regarded solely as an agenda to appease pro-Western influences, conservative groups are likely to use the issue to build popular support against the government that brings about such changes. This pressure will be based not upon legitimate concerns of complying with Islamic law or philosophy, which was one of the first systems of governance that gave women legal rights, but will be based upon attempts to discredit the new government in order to gain more support and power (Abirafeh, 2009).

Education is another issue related to the gender in Afghanistan. Girls' access to education has improved in urban centers, but progress has been limited in rural areas. Article 43 of the Afghan Constitution declares that "Education is the right of all citizens of Afghanistan, which shall be offered up to the B.A." (Supra) Many claim that education for girls is a basic human right. The constitution stays symbolic since women's illiteracy rate in Afghanistan is the highest in the world. In the past fifteen years the number of girls going to school is still not high as it was in the first years when the Taliban were overthrown. There are several reasons behind the non-attendance of girls to schools.

The first reason is that most girls' schools have been destroyed by the Taliban in the rural areas or warned by the Taliban that if girls go to school they will be burnt. As a result, it made families take out their daughters from the schools. The other reason is early marriages of girls at an age when they should be at secondary or high schools.

The transitional government of Afghanistan conveyed improvement for women in certain limited parts of big cities, girls went to school and some women were allowed to work outside the home in the capital, Kabul and other major cities. But the situation for women is worsening in the rest of the country. In most areas, rape and forced marriage are on the rise, 
women continue to wear the burqa out of fear, and are being traded in the settlement of debts. Women face discrimination from all society. Violence against women is accepted by the community and not addressed by the government (Dossa, 2014).

There is a viewpoint widely accepted by Afghan society generally that only men have the right of education according to Islam and that this is forbidden to women and girls. Furthermore, it is also believed that if women go outside from the home for education and to work this is a disgrace or a dishonor for them. Conversely opponents assert that education in Islam is not a right, but an obligation, regardless of gender quoting the Prophet Mohammad as declaring that the pursuit of knowledge is obligatory for every Muslim, irrespective of whether one is male or female (Jones, 2007).

However, even for those who consider and believe that the role of women should be strictly limited to the household and family sphere, there are four strong justifications for investing in educating girls that do not depend on economic returns. First, education improves women's own health, mainly in reducing maternal mortality where Afghanistan has one of the highest maternal mortality rates in the world (Heath \& Zahedi, 2011). Second, education improves the health of women's own children - mainly through better information, improved decisions, more useful use of medical services. Third, improvements in women's education are likely to improve the education of their children - male and female. Fourth, education of women improves their productivity in household responsibilities. In order to establish a stable society it is essential that women should know their rights. (Kargar, 2012).

In making policies and laws aimed at attaining and maintaining Afghan women's rights, it is important to understand the impacts it will have upon the development of children. When women have equal opportunities for education, employment, and health care, it will not only improve their own lives, but will likely have positive impacts on their families. For example, an educated woman is more likely to have the tools necessary to educate her children. A woman with economic resources is more likely to be able to afford health care for her children (Jalalzai \& Jefferess, 2011).

\section{Conclusion}

Years of conflict and war have over affected women's opportunities for education, training, and economic development. This, in turn, has made it even more difficult for women to advance in all areas of life in Afghanistan. It is these women who have lived a five-year nightmare under the Taliban regime including a deputy prime minister - Dr. Sima Samar. (Armstrong, 2002).

An important fact is that in Afghanistan there are opportunities for females so that they can have education and other much needed trainings. Cultural barriers that prohibit females from several activities and actions, violation of customs and culture against women's rights such as Jirgas (councils of male elders), are other issues related to the issue of gender in Afghanistan.

Early child and forced marriages, selling daughters and exchanging daughters are related issues to gender which exist mostly in rural areas. Parents and families often justify child marriages by claiming it ensures a better future for their daughters. Parents and families marry off their younger daughters as a means of gaining economic security and status for themselves as well as for their daughters. Insecurity, conflict and social crises also support 
early marriage.

According to a 2006 report by the UN an estimated 57 percent of girls in Afghanistan were married before the age of 16 (Ghanim, 2009). Economic reasons are said to play a significant role in such marriages. Due to the common practice of "bride money," the girl-child becomes an asset exchangeable for money or goods. Families see committing a young daughter (or sister) to a family that is able to pay a high price for the bride as a viable solution to their poverty and indebtedness (Nawa, 2011). It is also the reason why they do not get education resulting in the high illiteracy of women.

There are a high percentage of girls at schools who want to continue their schools but this is a serious barrier. Such kinds of marriages affect women's career and their involvement in business. Even though in the case of women who benefit from education and later when married they try to choose jobs which will not affect their marriage.

It is clear to see that helping women ultimately means fixing everything else that is dysfunctional in Afghanistan (Armstrong, 2008). After all Women are in essence cogs in rebuilding society (Skaine, 2001). The future hopes of Afghan women centre around peace with justice, transparency and inclusion and no illusions about a moderate Taliban (US Congress, 2010).

The gender order is not historically static, but changes over time and has relationships with other systems of oppression. The term does not reflect a particular gender hierarchy, yet the reality in most countries it is one of patriarchy. In Afghanistan in particular, patriarchy alone however, is an insufficient argument and could serve to confuse the agency of both women and men (Abirafeh, 2009).

\section{References}

Abirafeh, L. (2009). Gender and International Aid in Afghanistan: The Politics and Effects of Intervention. Jefferson, North Carolina: McFarland.

Alikuzai, H. W. (2011). From Aryana-Khorasan to Afghanistan: Afghanistan History in 25 Volumes. Bloomington, Indiana: Trafford Publishing.

Alikuzai, H. W. (2013). A Concise History of Afghanistan in 25 Volumes, Volume 1. Bloomington, Indiana: Trafford Publishing.

Amstutz, B. (1994). Afghanistan: The First Five Years of Soviet Occupation. Collingdale, Pennsylvania: Diane Publishing.

Armstrong, S. (2002). Veiled threat: The hidden power of the women of Afghanistan. Four Walls Eight Windows.

Armstrong, S. (2008). Bitter Roots Tender Shoots: The Uncertain Fate Of Afghanistan's Women. Penguin Canada.

Billaud, J. (2015). Kabul Carnival: Gender Politics in Postwar Afghanistan. Philadelphia, Pennsylvania: University of Pennsylvania Press. https://doi.org/10.9783/9780812291148

Brodsky, A. E. (2004). With all our strength: The revolutionary association of the women of Afghanistan. Psychology Press.

Bush, L. (2017). We Are Afghan Women: Voices of Hope. George W. Bush Institute, Simon and Schuster. 


\section{Macrothink Institute ${ }^{\text {TM }}$}

Dossa, P. (2014). Afghanistan Remembers: Gendered Narrations of Violence and Culinary Practices. Toronto: University of Toronto Press.

Dupree, L., \& Albert, L. (1974). Afghanistan in the 1970s. Ann Arbor, Michigan: University of Michigan.

Ellis, D. (2000). Women of the Afghan war. Greenwood Publishing Group.

Emadi, H. (2002). Repression, Resistance, and Women in Afghanistan. Westport Connecticut: Greenwood Publishing Group.

Ghanim, D. (2009). Gender and Violence in the Middle East. Westport, Connecticut: Praeger.

Hancock, L. (2011). A Place at the Table: Safeguarding women's rights in Afghanistan. Rugby: Oxfam, 2011.

Heath, J., \& Zahedi, A. (2011). Land of the Unconquerable: The Lives of Contemporary Afghan Women. Berkeley, California: University of California Press. https://doi.org/10.1525/california/9780520261853.001.0001

Jalalzai, Z., \& Jefferess, D. (2011). Globalizing Afghanistan: Terrorism, War, and the Rhetoric of Nation Building. Durham, North Carolina: Duke University Press. https://doi.org/10.1215/9780822394211

Jones, A. (2007). Kabul in Winter: Life Without Peace in Afghanistan. London: Macmillan.

Kargar, Z. (2012). Dear Zari: Stories from Women in Afghanistan. Random House.

Kumar, B. (2004). Encyclopaedia of Women in South Asia: Afghanistan. New Delhi: Gyan Publishing House.

McChesney, R., \& Mehdi, K. M. (2012). The History of Afghanistan. Leiden: Brill.

Mehta, S. (2002). Women for Afghan Women: Shattering Myths and Claiming the Future. London: Macmillan.

Meyerowitz, J. J. (2003). History and September 11th: Critical perspectives on the past. Philadelphia, Pennsylvania: Temple University Press.

Nawa, F. (2011). Opium Nation: Child Brides, Drug Lords, and One Woman's Journey Through Afghanistan. New York, New York: Harper Collins.

Nordberg, J. (2014). The Underground Girls of Kabul: In Search of a Hidden Resistance in Afghanistan. Broadway Books.

Rasanayagam, A. (2005). Afghanistan: A Modern History. London: I.B.Tauris.

Rostami-Povey, E. (2007). Afghan Women: Identity and Invasion. London: Zed Books.

Runion, M. (2007). The History of Afghanistan. Westport, Connecticut: Greenwood Publishing Group.

Skaine, R. (2001). The women of Afghanistan under the Taliban. McFarland.

Skaine, R. (2008). Women of Afghanistan in the post-Taliban era: how lives have changed and where they stand today. McFarland.

United States. Congress. Senate. Committee on Foreign Relations. Subcommittee on International Operations and Organizations, Human Rights, Democracy, and Global Women's Issues. (2010). Afghan Women and Girls: Building the Future of Afghanistan : Joint Hearing Before the Subcommittee on Near Eastern and South and Central Asian Affairs and the 


\section{Macrothink}

Journal of Social Science Studies

ISSN 2329-9150

2017, Vol. 4, No. 2

Subcommittee on International Operations and Organizations, Human Rights, Democracy, and Global Women's Issues.

Yigit, S. (2009). Afghanistan 2010: Slipsiding Away. Bilim Jana Tarbiya, 1(10), 8-12.

\section{Copyright Disclaimer}

Copyright for this article is retained by the author(s), with first publication rights granted to the journal.

This is an open-access article distributed under the terms and conditions of the Creative Commons Attribution license (http://creativecommons.org/licenses/by/3.0/). 